\title{
The Turin Process and the Development of Qualifications Frameworks for Working Specialties in Russia and European Countries
}

\author{
Maria Sinyagovskaya ${ }^{1, a *}$
}

\begin{abstract}
1 Fund for Support of International Economic and Humanitarian Programs, 115280, 4/1 1st Avtozavodsky proyezd, Moscow, Russia
\end{abstract}

amaria.sinyagovskaya@gmail.com

${ }^{*}$ Corresponding author

Keywords: turin process, vocational educational systems, Europe, Russia, transparency of education, Copenhagen Process, comparative features, dual vocational education, working specialties

\begin{abstract}
The article discusses the process of developing vocational education in a number of EU countries and Russia in the context of the Turin process. Comparative features of vocational education systems of Germany, Poland, Finland, and Denmark are revealed. The genesis of dual vocational education and the difference in educational goals in the compared countries is studied, the arguments of the choice of countries for comparison are presented. The features of European support for dual vocational education, as well as general and excellent educational goals and objectives in the compared countries are outlined.
\end{abstract}

\section{Introduction}

When choosing the EU countries (Germany, Poland, Denmark, and Finland) for a comparative analysis, we were guided by the fact that they had fundamentally different professional education systems, and each has its own individuality. All compared countries are at the stage of forming their own national qualifications frameworks, and each country has its own, different from each other, initial conditions in the economic, legal and political fields, which is reflected in the national requirements of these countries to the qualification requirements of corresponding professions.

The choice made allows, among other things, to compare Eastern European and Western European countries, to analyze the peculiarities of the development of the vocational education system of countries participating in the process of European integration in different times. It will also allow assessing the prospects for rapprochement between different positions of the EU countries on the formation of a common European educational space.

\section{Methodology}

The problem of comparability of qualifications and transparency within the educational space has been studied, the solution of which allows bringing national vocational education systems to a common denominator in terms of qualification requirements and levels. Based on the extensive material in the original language (European Center for the Development of Vocational Training, Deutscher qualifikation srahmen), differences in approaches to the terms "training", "learning outcomes", and "qualification" are analyzed from the standpoint of developing a qualification framework (national and European).

\section{Study}

The introduction of educational standards is aimed at a modified, result-oriented management of educational systems and is intended to improve the quality of educational processes (H. Altrichter, H. J. Abs, J. Bellmann, S. Schweizer, C. Thiel) [1, 4, 2, 5, 3].

A comparative analysis of vocational education systems in various European countries led to the conclusion that by the end of the 1980s, there were no serious prerequisites for starting a European cooperation in education, but as a result of the turbulent processes of globalization in the economy and the heightened processes of European integration, the situation changed significantly: the national vocational 
education systems of the European Union countries were in a fairly tough competition to each other, and they needed to build relations of international cooperation in order to overcome their differences.

Cooperation in the field of vocational education took shape as an independent European direction after the adoption by the European Union countries in November 2002 of the Copenhagen Declaration, which provided for joint programs being implemented in full transparency, their implementation within strict deadlines, and the recognition of uniform qualification requirements for professions by all member countries (Table 1).

TABLE 1. STAGES OF DEVELOPMENT OF REQUIREMENTS FOR THE CONTENT AND QUALITY OF TRAINING IN THE EU.

\begin{tabular}{|c|c|c|c|}
\hline Stage & Novelty & Tasks & $\begin{array}{l}\text { Mechanisms and activities for } \\
\text { the implementation of tasks }\end{array}$ \\
\hline $\begin{array}{l}\text { Copenhagen } \\
\text { Declaration, } 2002\end{array}$ & $\begin{array}{l}\text { Integration activity in } \\
\text { the field of vocational } \\
\text { education. }\end{array}$ & $\begin{array}{l}\text { Specify tasks in the field of } \\
\text { vocational education, in the } \\
\text { field of employment; } \\
\text { determine ways to achieve } \\
\text { greater student mobility, } \\
\text { clarify the procedure for } \\
\text { recognizing qualification } \\
\text { requirements for a significant } \\
\text { list of professions }\end{array}$ & $\begin{array}{l}\text { Creation of national and pan- } \\
\text { European qualifications frame- } \\
\text { works, standardization of } \\
\text { information on the qualifications } \\
\text { and professional experience of } \\
\text { employees in the European Union } \\
\text { (Europass), European social } \\
\text { partners (negotiation process and } \\
\text { agreement between employers' } \\
\text { associations and trade unions), } \\
\text { virtual online communities }\end{array}$ \\
\hline $\begin{array}{l}\text { Maastricht } \\
\text { Communique, } 2004\end{array}$ & $\begin{array}{l}\text { Principles of } \\
\text { reforming national } \\
\text { vocational education } \\
\text { systems, including } \\
\text { the requirement to } \\
\text { strengthen interaction } \\
\text { between all actors at } \\
\text { the national, regional } \\
\text { and local levels }\end{array}$ & $\begin{array}{l}\text { The task of facilitating the } \\
\text { mobility of workers and } \\
\text { students between countries, } \\
\text { increasing employment } \\
\text { opportunities, expanding } \\
\text { advice on the choice of the } \\
\text { form and method of training }\end{array}$ & $\begin{array}{l}\text { The introduction of tools such as } \\
\text { Europass, ECVET, and EQR, it is } \\
\text { possible to significantly increase } \\
\text { the mobility of workers, } \\
\text { employees, students, and thus } \\
\text { contribute to raising the level of } \\
\text { vocational education }\end{array}$ \\
\hline $\begin{array}{l}\text { "Europe 2020" } \\
\text { Strategies }\end{array}$ & $\begin{array}{l}\text { Ensuring the mobility } \\
\text { of personnel in the } \\
\text { European space, } \\
\text { improving the quality } \\
\text { of vocational } \\
\text { education and } \\
\text { creating national } \\
\text { qualifications } \\
\text { frameworks. }\end{array}$ & $\begin{array}{l}\text { Two tasks were added that } \\
\text { require greater social cohesion } \\
\text { and fostering an objective } \\
\text { attitude towards reality, as } \\
\text { well as calling for the support } \\
\text { of innovations, including } \\
\text { entrepreneurial activity, at all } \\
\text { levels of the educational } \\
\text { process. }\end{array}$ & $\begin{array}{l}\text { The quota of students who "drop } \\
\text { out of school" should be reduced } \\
\text { to } 10 \% \text { by } 2020 \text {; the quota of the } \\
\text { population between the ages of } 30 \\
\text { and } 34 \text { years, having a higher } \\
\text { education or comparable with this } \\
\text { level, should increase to } 40 \% \text {; the } \\
\text { quota of the population that shares } \\
\text { the views of "lifelong learning" } \\
\text { must be at least } 15 \% \text { of the adult } \\
\text { population; by } 2020 \text {, at least half } \\
\text { of } 15 \text {-year-olds should be fluent } \\
\text { in one foreign language and } 75 \% \\
\text { should learn a second language }\end{array}$ \\
\hline $\begin{array}{l}\text { Global Vision of } \\
\text { Vocational } \\
\text { Education in } 2020\end{array}$ & $\begin{array}{l}\text { Strategic objectives } \\
\text { for the period 2011- } \\
2020 \text {, which are } \\
\text { based on this vision, } \\
\text { short-term goals for } \\
\text { the national level for } \\
\text { the period 2011-2014 } \\
\text { and proclaimed } \\
\text { general principles of } \\
\text { personal } \\
\text { responsibility for the } \\
\text { implementation of the } \\
\text { Copenhagen process. }\end{array}$ & $\begin{array}{l}\text { Until 2014, all countries } \\
\text { should have national } \\
\text { qualifications frameworks that } \\
\text { will require closer interaction } \\
\text { of social partners with } \\
\text { educational institutions and set } \\
\text { new challenges for practice. }\end{array}$ & $\begin{array}{l}\text { Coordinated use of European and } \\
\text { national instruments in ensuring } \\
\text { the transparency of activities, } \\
\text { mutual recognition of } \\
\text { qualification requirements, } \\
\text { ensuring the quality of education } \\
\text { and mobility. }\end{array}$ \\
\hline
\end{tabular}




\begin{tabular}{|c|c|c|c|}
\hline Stage & Novelty & Tasks & $\begin{array}{l}\text { Mechanisms and activities for } \\
\text { the implementation of tasks }\end{array}$ \\
\hline Turin process & $\begin{array}{l}\text { It is based on a } \\
\text { participatory } \\
\text { approach based on } \\
\text { the participation of } \\
\text { representatives of all } \\
\text { stakeholders in } \\
\text { collecting for } \\
\text { information reports, } \\
\text { national focus } \\
\text { evaluating it, and } \\
\text { groups } \\
\text { discussions. }\end{array}$ & $\begin{array}{l}\text { Development of tools for self- } \\
\text { assessment and monitoring the } \\
\text { development of vocational } \\
\text { education, taking into account } \\
\text { international development } \\
\text { trends. }\end{array}$ & $\begin{array}{l}\text { National reports are structured in } \\
\text { a single structure, including } \\
\text { sections relating to the current } \\
\text { situation in the software in the } \\
\text { country, vision for the future, as } \\
\text { well as the effectiveness of the } \\
\text { system in terms of compliance of } \\
\text { the vocational education system } \\
\text { with the tasks of developing the } \\
\text { national economy and labor } \\
\text { markets, assessing the role of } \\
\text { vocational education in ensuring } \\
\text { equal opportunities for learning, } \\
\text { sharing responsibility for } \\
\text { vocational education and training, } \\
\text { and improving systems quality } \\
\text { assurance, financing, } \\
\text { management, including the } \\
\text { contribution of vocational } \\
\text { education to innovation, the } \\
\text { development of partnership and } \\
\text { entrepreneurship. }\end{array}$ \\
\hline
\end{tabular}

First, basic vocational education and advanced training serve a dual purpose: on the one hand, they support employment and promote economic growth, and on the other hand, they respond to growing social challenges and, in particular, support the social unity of the nation.

The implications of the Copenhagen and Turin process on the educational policies of the EU countries were significant and soon became apparent. Such important processes as the development of a national qualification framework, taking into account the need to create a pan-European qualification framework (EQR), became possible only as a result of the Copenhagen process [10]. The framework process has greatly contributed to the creation of a transparent and flexible national qualification system.

Consider results of the Russian practice in terms of the implementation of the provisions of the Turin process in the modification of the secondary vocational education system. So, for example, at the expense of the federal budget in 2016, work was carried out to improve the skills of 700 teachers (masters of industrial training) in the 10 most promising and sought-after professions and specialties. In 2016, the experiment on the introduction of dual training, conducted under the auspices of the Agency for Strategic Initiatives and the Ministry of Education and Science of the Russian Federation, ended covering 13 regions, 105 educational institutions, and more than 1,000 enterprises. As a result, models of practice-oriented training of personnel were worked out, when enterprises were directly involved in the educational process and financed it to a large extent. The Ministry of Education and Science of Russia, together with ASI and FIRO, developed guidelines for the implementation of a dual model for training the highly qualified personnel, and the experimental results were the basis for scaling up a model of practice-oriented (including dual) vocational education in the constituent entities of the Russian Federation until 2020. Since 2016, in all 85 regions of the Russian Federation launched the monitoring of the quality of training in the framework of the Russian Federation State rogram “Available Environment” for 2011 - 2020. The Russian Ministry launched a project to create the basic professional educational organizations that would provide support to regional systems of inclusive vocational training of persons with disabilities.

So, in view of the differences in status and importance of education, there are many types of student learning. In individual countries, the combination of school and vocational training is evaluated differently. They even call it differently in every country. For example, in Germany, sometimes dual vocational education is called industrial training (German: Lehre). Compared to this, at the European level, the term alternate learning (German alternierende Ausbildung) is used, which should be maintained and developed according to the position of the European Commission. The European concept of the so-called alternating education specifies its details and, at the same time, largely refers to the dual system of vocational education 
in Germany. Learning places of the German dual system are the main components of study time. There is a direct relationship between the dual system of vocational education in Germany and the concept of alternating education. The European model is characterized by a close relationship between an enterprise (practice) and a vocational school (theory), with study periods following each other. Due to the fact that they follow each other, there is a conflict of potentials within the dual education system in Germany itself, since there is no systematic cooperation between an educational enterprise and a vocational school, and these learning places themselves can hardly be called equivalent because of the different functions they perform.

TABLE 2. THE INDICATORS MONITORING THE QUALITY OF PERSONNEL TRAINING TAKING INTO ACCOUNT RECOMMENDATIONS OF THE TURIn Process (REPORT TURIN Process 2016-2017, Russia).

\begin{tabular}{|c|c|}
\hline Indicator & Value \\
\hline $\begin{array}{l}\text { The share of professional educational organizations in which training is carried out on the } 50 \\
\text { most promising and demanded occupations in the labor market and specialties requiring } \\
\text { secondary vocational education (hereinafter, promising and in-demand professions and } \\
\text { specialties) in the total number of professional educational organizations. }\end{array}$ & $\begin{array}{l}50 \% \\
\text { by } 2020\end{array}$ \\
\hline $\begin{array}{l}\text { Percentage of managers and teachers of vocational educational organizations who have been } \\
\text { trained in additional professional programs on training in the } 50 \text { most promising and popular } \\
\text { professions and specialties; the total number of managers and teachers of vocational educational } \\
\text { organizations engaged in the training of personnel in the } 50 \text { most promising and sought-after } \\
\text { professions and specialties. }\end{array}$ & $\begin{array}{l}70 \% \\
\text { by } 2020\end{array}$ \\
\hline $\begin{array}{l}\text { The share of the subjects of the Russian Federation, whose teams participate in the national } \\
\text { championships of professional skill, including the "WorldSkills Russia" national championship, } \\
\text { in the total number of subjects of the Russian Federation }\end{array}$ & $\begin{array}{l}90 \% \\
\text { by } 2020\end{array}$ \\
\hline $\begin{array}{l}\text { Percentage of students of professional educational organizations studying for the } 50 \text { most } \\
\text { promising and sought-after professions and specialties (TOP 50) participating in "WorldSkills } \\
\text { Russia" regional professional skills championships, regional stages of All-Russian professional } \\
\text { skills competitions and industry championships, in the total number of students of professional } \\
\text { educational organizations studying for the } 50 \text { most promising and sought-after professions and } \\
\text { specialties. }\end{array}$ & $\begin{array}{l}50 \% \\
\text { by } 2020\end{array}$ \\
\hline $\begin{array}{l}\text { Percentage of graduates of professional educational organizations who have completed training } \\
\text { in the } 50 \text { most promising and sought-after professions and specialties who have received a } \\
\text { certificate from independent centers for the assessment and certification of qualifications or } \\
\text { have received a "professionalism medal" in accordance with the standards of "WorldSkills". }\end{array}$ & $\begin{array}{l}40 \% \\
\text { by } 2020\end{array}$ \\
\hline
\end{tabular}

In most countries of the European Union, the main burden of vocational training lies on vocational schools, where training takes a full week. Also, unlike in Germany, in most countries of the European Union, the link between a vocational school and an educational enterprise is not so close. Therefore, the attention paid in Germany to educational enterprise and industrial training is understood in other European countries with great difficulty.

In the field of vocational education, Germany has a highly developed system, which most European countries cannot boast of, where vocational education and training are perceived as a second choice, as a rule, for poorly performing students in schools and gymnasiums [6].

In all four compared countries, education is an important tool in achieving the desired effect on the activities of enterprises, the economy and society as a whole, including rising wages, high employment and social integration. With regard to the activities of enterprises, the main advantages of education are the growth of product quality, labor productivity and great motivation of staff. In economics, vocational education contributes to greater growth and with it the quality of life of the population of the whole country and in parallel with this reduction of social problems. In all four educational systems, equality of chance is considered an important prerequisite for high quality. In Finland and Denmark, they see their strength in the equal quality of the educational offer, since the differences between primary vocational education within the school in terms of curricula are extremely small.

Considering the political strategy in the field of education in Poland, it should be noted that the country pays all attention to students so that they feel confident in a united Europe. The terms "differentiation" and "individualization" play a big role. The variety of content, forms, types of institutions, 
personification of participants in the educational process are all units of measurement of the degree of novelty of the Polish educational system. Expansion and renewal of work opportunities in the autonomy of different participants in the Polish educational system could be an essential step towards building a modern European education system [9].

The common for the compared national systems of vocational education is the unity of the goals set in the field of educational policy, the implementation of which is aimed at ensuring the growth of the quality of products, labor productivity, preservation of the social world. The unity of political goals does not eliminate the differences inherent in national education systems, which are expressed in excellent legal and financial features, different traditions of teaching and educational practice. It should be noted that the German dual system of vocational education with a small degree of probability will be integrated into the so-called alternating system of vocational education that is widespread throughout Europe [8]

\section{Conclusion}

Thus, a historical retrospective of the European integration process allowed to state that since 2002, the moment of the adoption of the Copenhagen Declaration, a pan-European system of vocational education has been created. This system takes into account the need to ensure a high level of employment of the EU population, maintain stable rates of economic growth and competitiveness, the requirements of a "green economy", demographic changes and international migration.

As a result, the analysis of the scientific literature and the final documents of the European Commission made it possible to ascertain that the Copenhagen and Turin processes over the past decade have contributed to the realization of the importance of vocational education both at the European and national levels. This clearly demonstrates the content of the European directives adopted during this time and the developed principles aimed at making the process of obtaining qualifications more transparent, easier to compare, and easier to transfer from country to country, which ultimately guarantees the flexibility and high quality of European professional of education.

\section{References}

[1] Altrichter, H., Schley, W., \& Schratz, M. (Ed.). (2010). Handbuch zur Schulentwicklung. Germany: BoD-Books on Demand.

[2] Bellmann, J., \& Müller, T. (2011). Wissen, was wirkt. Kritik evidenzbasierter Pädagogik. Wiesbaden, Germany.

[3] Hangartner J., \& Heinzer M. (2016). Einleitung: Die Gemeinde in der Educational Governance. Gemeinden in der Schul-Governance der Schweiz (pp. 1-29). Wiesbaden, Germany: Springer VS.

[4] Hoskins, B., Kerr, D., Abs, H. J., Janmaat, J. G., Morrison, J., Ridley, R., \& Sizmurq, J. (2012). Analytic report: participatory citizenship in the European Union Institute of Education. Brussels, Belgium.

[5] Reiss, S., Tillmann, A., Schreiner, M., Schweizer, K., Krömker, D., \& Moosbrugger, H. (2009). Online-Self-Assessments zur Erfassung studienrelevanter Kompetenzen. Zeitschrift für Hochschulentwicklung.

[6] Sinyagovskaya, M. B. (2014). Features of European support for dual professional education. Innovations and investments, 10, pp. 294-296.

[7] Sinyagovskaya, M. B. (2013). Features of the development of the qualification framework of Germany in the context of European integration. World of Science, Culture, Education, 5, pp. 58-60.

[8] Sinyagovskaya, M. B. (2017). The process of developing a European and national qualification framework on the example of EU countries. Education Management: Theory and Practice, 1(25).

[9] Sinyagovskaya, M. B. (2017). Retrospective of the formation of the modern European market of educational programs. Modern science: actual problems of theory and practice. Series: Humanities, 3, pp. 83-86. 
[10] Sinyagovskaya, M. B., Arinushkina, A. A. (2016). Copenhagen process in the context of the modernization of European education. Scientific notes IUO RAO, 4-1, pp. 209-214. 